\title{
Stable carbon and nitrogen incorporation in blood and fin tissue of the catfish Pterygoplichthys disjunctivus (Siluriformes, Loricariidae)
}

\author{
Donovan P. German • Richard D. Miles
}

Received: 30 April 2010/Accepted: 3 August 2010/Published online: 2 September 2010

(C) The Author(s) 2010. This article is published with open access at Springerlink.com

\begin{abstract}
A feeding trial was performed in the laboratory with the catfish species Pterygoplichthys disjunctivus to determine stable carbon $\left({ }^{13} \mathrm{C}\right)$ and nitrogen $\left({ }^{15} \mathrm{~N}\right)$ turnover rates and discrimination factors in non-lethally sampled tissues (red blood cells, plasma solutes, and fin). A second feeding trial was conducted to determine what $P$. disjunctivus could assimilate from low-quality wood-detritusrefractory polysaccharides (e.g., cellulose), or soluble wood-degradation products inherent in wood-detritus. This was performed by feeding the fish an artificial wood-detritus diet with fibrous $\left(\delta^{13} \mathrm{C}=-26.36 \% ; \delta^{15}\right.$ $N=2.13 \%$ o $)$ and soluble portions $\left(\delta^{13} \mathrm{C}=-11.82 \%\right.$; $\delta^{15} N=3.39 \%$ o) that had different isotopic signatures and monitoring the dynamics of isotopic incorpora-
\end{abstract}

Electronic supplementary material The online version of this article (doi:10.1007/s10641-010-9703-0) contains

supplementary material, which is available to authorized users.

D. P. German $(\bowtie)$

Department of Biology, University of Florida,

Gainesville, FL 32611, USA

e-mail: dgerman@uci.edu

R. D. Miles

Department of Animal Sciences, University of Florida,

Gainesville, FL 32611, USA

Present Address:

D. P. German

Department of Ecology and Evolutionary Biology,

University of California,

Irvine, CA 92697, USA tion in the different tissues over time. Plasma solutes turned over more quickly than red blood cells for ${ }^{13} \mathrm{C}$ and ${ }^{15} \mathrm{~N}$. However, in contrast to previous studies of juvenile fishes, $\mathrm{C}$ and $\mathrm{N}$ incorporation was primarily driven by catabolic tissue turnover as opposed to growth rate. Tissue-diet discrimination factors for ${ }^{15} \mathrm{~N}$ varied from 4.08 to $5.17 \%$, whereas they were $<2 \%$ o for ${ }^{13} \mathrm{C}$ (and less than $0.3 \%$ for plasma and red blood cells). The results of trial two suggested that $P$. disjunctivus could not assimilate refractory polysaccharides. Moreover, the $\delta^{13} \mathrm{C}$ and $\delta^{15} \mathrm{~N}$ signatures of wild-caught $P$. disjunctivus from Florida confirmed their detrital trophic standing in Floridian aquatic ecosystems.

Keywords Diet shift · Stable isotopes · Isotopic discrimination $\cdot$ Food deprivation $\cdot$ Detritus

\section{Introduction}

Unlike gut content analyses, which provide a snapshot of an animal's diet, stable isotopic analyses integrate an animal's diet over time. Thus, the use of carbon $\left({ }^{13} \mathrm{C}\right)$ and nitrogen $\left({ }^{15} \mathrm{~N}\right)$ stable isotopes have become commonplace in dietary reconstruction for fishes. Few investigations, however, have determined turnover rates and tissue-diet discrimination factors $\left(\Delta \mathrm{X}=\delta \mathrm{X}_{\text {tissue }}-\delta \mathrm{X}_{\text {diet }}\right)$ of fish tissues in the laboratory before gathering animals and tissues from nature (Hesslein et al. 1993; MacAvoy et al. 2001; Jardine et 
Table 1 Overall isotopic signatures of the pelleted algae and artificial wood-detritus diets fed to Pterygoplichthys disjunctivus. Proportions of ingredients composing the artificial wood-detritus and the isotopic signatures $\left(\delta^{13} \mathrm{C}\right.$ and $\left.\delta^{15} \mathrm{~N}\right)$ of each are also shown

\begin{tabular}{|c|c|c|c|}
\hline Diet component & $\mathrm{g} / 100 \mathrm{~g}$ & $\delta^{13} \mathrm{C}$ & $\delta^{15} \mathrm{~N}$ \\
\hline \multicolumn{4}{|l|}{ Algae diet } \\
\hline Total isotopic signature & - & $-22.97 \pm 0.02 \%$ & $2.43 \pm 0.25 \%$ \\
\hline Lipid extracted signature & - & $-22.02 \pm 0.19 \%$ & $2.26 \pm 0.16 \%$ \\
\hline \multicolumn{4}{|l|}{ Wood diet } \\
\hline Bulk wood $^{\mathrm{a}}$ & 80.0 & $-26.36 \pm 0.25 \%$ & $2.13 \pm 0.20 \%$ \\
\hline Cellulose and hemicellulose ${ }^{b}$ & $(40.8)$ & $-25.39 \pm 0.12 \%$ & $\mathrm{~N} / \mathrm{A}$ \\
\hline Corn gluten meal ${ }^{\mathrm{c}}$ & 9.0 & $-12.98 \pm 0.11 \%$ & $3.26 \pm 0.25 \%$ \\
\hline Xanthan gum ${ }^{\mathrm{d}}$ & 6.0 & $-9.64 \pm 0.05 \%$ & $1.46 \pm 0.01 \%$ o \\
\hline Corn meal ${ }^{\mathrm{c}}$ & 2.1 & $-10.65 \pm 0.06 \%$ & $4.34 \pm 0.31 \%$ \\
\hline L-Lysine ${ }^{c}$ & 1.0 & $-14.63 \pm 0.00 \%$ & $0.01 \pm 0.00 \%$ \\
\hline Vitamin premix ${ }^{\mathrm{c}}$ & 1.0 & $-27.59 \pm 1.12 \%$ & $2.63 \pm 0.31 \%$ \\
\hline Trace mineral mix ${ }^{c}$ & 0.5 & $\mathrm{~N} / \mathrm{A}$ & $\mathrm{N} / \mathrm{A}$ \\
\hline Water stable vitamin $C^{\mathrm{c}}$ & 0.4 & $-18.90 \pm 0.01 \%$ & N/A \\
\hline Total isotopic signature & - & $-23.42 \pm 0.18 \%$ & $2.30 \pm 0.20 \%$ \\
\hline
\end{tabular}

Values are mean $( \pm$ SEM)

${ }^{a}$ bulk-wood from decomposed water oak (Quercus nigra)

${ }^{\mathrm{b}}$ cellulose and hemicellulose (collectively called holo-cellulose) isolated from wood following Gaudinski et al. (2005); proportion determined on an organic matter basis, and mass presented represents 51.1\% (German 2009b) of $80 \mathrm{~g}$ of bulk wood; not an additional ingredient

${ }^{\mathrm{c}}$ gifts from Hartz-Mountain Corp. and intended specifically for use in fish food

dindigestible non-starch polysaccharide added as a binding agent to keep pellets bound in water

al. 2004; Sakano et al. 2005; Suzuki et al. 2005; Guelinckx et al. 2007; Vollaire et al. 2007; Zuanon et al. 2007). These investigations suggest that empirically determined turnover rates and tissue-diet discrimination factors are essential for interpreting field isotopic signatures in a range of species. For instance, turnover rates vary among tissues [e.g., ${ }^{15} \mathrm{~N}$ turnover is nearly $9 \mathrm{X}$ faster in liver than in muscle of sand goby (Pomatoschistus minutus; Guelinckx et al. 2007)], and tissue-diet discrimination factors often differ from averages used to reflect trophic level shifts (i.e., $1 \%$ for $\delta^{13} \mathrm{C}, 3.4 \%$ for $\delta^{15} \mathrm{~N}$ for muscle tissue; Fry and Sherr 1984; Focken 2004; Fry 2007). Therefore, without knowledge of expected discrimination factors and turnover rates, it is difficult to discern the dietary history of a fish with stable isotopes and to know the time frame at which one is operating.

Despite the potential lethality involved in its sampling - especially for smaller fishes-muscle is the tissue most commonly used to trace the dietary histories of fishes with stable isotopes (Pinnegar and Polunin 1999; Kelly et al. 2006). However, recent investigations have shown that "non-lethally" sampled tissues, such as fin (Suzuki et al. 2005) or mucus (Church et al. 2009), can also be used for stable isotopic analyses of fish populations. Blood, which can also be sampled non-lethally from many fish species, has heretofore been used sparingly in fish stable isotopic investigations (e.g., McIntyre and Flecker 2006). This is despite the point that blood contains two "tissues" (red blood cells and plasma/serum) that turnover at different rates (Seminoff et al. 2007; Reich et al. 2008), providing important comparative data for understanding dietary variation over time (Perga and Gerdeaux 2005).

Isotopic incorporation into a fish's tissues is affected by many factors, including growth rate and catabolic tissue turnover. Because most studies of isotopic incorporation rates in fish tissues have been performed with quickly growing juvenile fishes, most estimates of isotopic turnover suggest a strong contribution of growth to this process (e.g., Hesslein et al. 1993; Jardine et al. 2004). To our knowledge, there have been no long-term studies with adult fishes in which isotopic incorporation in at least two tissues 
was examined and the contributions of growth vs. catabolic tissue turnover determined. This is a necessary step in our understanding of isotopic dynamics in fish tissues, especially since many stable isotopic investigations of wild-caught fishes utilize adult animals that grow slowly or seasonally (Perga and Gerdeaux 2005).

In this study we examined tissue isotopic turnover in Pterygoplichthys disjunctivus (Weber 1991), a detritivorous (German 2009b) suckermouth armored catfish (family Loricariidae), congeners of which are now found throughout central and southern Florida (Nico 2005; Nico et al. 2009), among other locations throughout the globe (Page and Robbins 2006; Mendoza et al. 2007), where they have caused considerable disturbance and have become the dominant fish taxa in some habitats (Nico 2005; Mendoza et al. 2007; Nico et al. 2009). Two stable isotopic turnover experiments were conducted. In trial one, turnover rates and discrimination factors of ${ }^{13} \mathrm{C}$ and ${ }^{15}$ $\mathrm{N}$ were established for red blood cells (RBCs), plasma solutes, and fin tissue of $P$. disjunctivus consuming a commercial algal diet. In trial two we determined what this species was capable of assimilating from low-quality detritus: refractory polysaccharides (e.g., cellulose) or soluble degradation products inherent in detritus. We did this by feeding the fish an artificial wood-detritus diet with fibrous $\left(\delta^{13} \mathrm{C}=-26.36 \%\right.$; $\delta^{15} N=2.13 \%$ ) and soluble components $\left(\delta^{13} \mathrm{C}=-11.82 \%\right.$; $\left.\delta^{15} N=3.39 \%\right)$ of different isotopic signatures and observing the dynamics of isotopic incorporation over time. We tested three hypotheses in this investigation: 1) plasma solutes, RBCs, and fin tissue have different rates of isotopic incorporation, making them dietary indicators on different time scales; 2) isotopic incorporation into plasma solutes and RBCs is driven primarily by catabolic tissue turnover in slowly growing adult fishes; and 3) P. disjunctivus poorly assimilates cellulose, suggesting that it does not directly contribute to the turnover of recalcitrant organic matter in Floridian aquatic ecosystems.

\section{Materials and methods}

Fish collection and maintenance in the laboratory

Twenty-two adult Pterygoplichthys disjunctivus were captured by hand while snorkeling from the Wekiva Springs complex in north central Florida $\left(28^{\circ} 41^{\prime} 48.9^{\prime \prime}\right.$
$\mathrm{N}, 81^{\circ} 23^{\prime} 27.84^{\prime \prime} \mathrm{W}$ ) in May 2005. Of the 22 fish, 19 were female. The fish were similar in length [mean \pm standard deviation (SD); $128.77 \pm 2.12 \mathrm{~mm}$ standard length (SL)] and mass (51.29 $\pm 2.19 \mathrm{~g})$. Upon capture, fish were placed in 128-L coolers of aerated river water and transported alive back to the University of Florida. Upon arrival, fish were randomly assigned, in pairs, to $75.6-\mathrm{L}$ aquaria equipped with mechanical filtration, containing dechlorinated tap water, and under a 12L:12D light cycle (German 2009b). We housed the fish in pairs because preliminary observations suggested that the fish were less stressed and commenced feeding immediately when in the presence of conspecifics. The thermostat in the aquarium laboratory was set at $25^{\circ} \mathrm{C}$ and the temperature and chemical conditions ( $\mathrm{pH}$, ammonia concentrations) of each tank were monitored daily to make sure they did not vary during the course of the experiment. The tanks were scrubbed, debris and feces siphoned out, and $95 \%$ of the water changed every 5 to 7 days to limit algal and microbial growth in the tanks as possible confounding food sources.

Tissues used for stable isotope analysis

Approximately $150 \mu \mathrm{L}$ of blood was drawn with a 23-gauge needle from the haemal arch just posterior to the anal fin of the fish, transferred to unheparinized capillary vials, and immediately centrifuged at 13 $000 \times g$ for $5 \mathrm{~min}$ to separate the RBCs, white blood cells, and plasma (Reich et al. 2008). Following the separation, the RBCs and plasma were placed in separate, sterile centrifuge vials, and the white blood cells were discarded. Fin clips (approximately $0.5 \mathrm{~g}$ wet weight) were taken with sterile scissors by cutting membranous tissue and soft rays (no thicker, hardened rays, and no bone) from the left or right pelvic fin, or the dorsal or ventral caudal fin, depending on the individual fish. The specific fin taken was used to identify individual fish in their respective aquaria, and thus, the same fin was clipped at each sampling interval from each individual fish. The fin tissue completely regenerated within the 30 days between sampling intervals (a common observation in fishes; Wills et al. 2008). The initial "steady state" fin tissue taken from an individual fish was used for isotope turnover analysis (representing days 1-29) in conjunction with regenerated fin in trial one, but only regenerated fin was used for trial two (see below). 
Stable isotope trial 1: initial turnover

Upon arrival in the laboratory, tissues were taken from four individual fish to provide an initial stable isotopic reading. Thereafter, fish were fed a commercial algal diet (Wardley ${ }^{\circledR}$ Premium Algae Discs, Hartz-Mountain Corporation, Secaucus, NJ) for 203 days (Table 1). Fish were offered and consumed seven discs per night, equating to approximately $6 \%$ of their body mass, on a wet mass basis, per day. For the first 100 days of the feeding trial, tissues were sampled from three to four fish (from different tanks) approximately every 5 days, whereas six to seven individuals were sampled every 10-11 days for the final 103 days of the experiment. The sampling regime was designed so that individual fish were sampled every 30 days, giving them ample time to recover from the blood draws and fin tissue biopsies. Loricariid catfishes are resilient animals, which lack scales, and endure handling stress with little side effects. For example, $P$. disjunctivus in this and previous investigations (German 2009b; German et al. 2010) always consumed food following handling. This is probably why this fish species (and its close relatives) are popular in the aquarium trade and are successful invaders in novel habitats. Thus, we expected little effect of handling stress on the outcome of this study.

Stable isotope trial 2: wood-detritus assimilation and negative control

After being fed the algae diet for 203 days, the fish were fed the algae discs but were not handled for 40 days. Thereafter, fish were divided into two groups: one group $(n=6)$ continued to be fed the algae diet (positive controls), and one group $(n=16)$ was switched to an artificial wood-detritus diet (experimental group). An additional six fish were captured from the wild in February 2006 to act as negative controls and were not fed for the duration of the experiment (see below).

The goal of this experiment was to examine whether $P$. disjunctivus could assimilate carbon from recalcitrant polymers (cellulose, hemicellulose, lignin), or if they simply digested and assimilated soluble degradation products found in detritus (e.g., $\alpha$-glucans, $\alpha$-glucosides, $\beta$-glucosides). Thus, we designed a diet that featured degraded wood (and its inherent fiber types) of one isotopic signature, and soluble components of another isotopic signature (Table 1). The wood was that of decomposed riparian water oak (Quercus nigra), collected from the

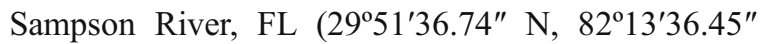
$\mathrm{W})$, and the soluble components were composed of corn gluten meal, corn meal, vitamins, and minerals (Table 1). A pelleted wood diet was prepared and offered to the fish as described by German et al. (2010). The fish consumed 10 pellets of the artificial wood-detritus diet per night, equating to approximately $8 \%$ of their body mass, on a wet mass basis, per day. The fish were fed the wood diet for 155 days, and tissues were taken every 5 days for the first 50 days of the experiment, and every 10 days for the remaining 105 days. Fish continuing to receive the algae diet (positive controls) were fed as described above for trial one.

Because previous observations suggested that $P$. disjunctivus did not gain weight on a wood-only diet in the laboratory (German 2009b), we included a group of fish that acted as negative controls. Six individuals ( $\mathrm{BM} \pm \mathrm{SD} ; 307.52 \pm 134.40)$ were deprived of food for the duration of the wood-feeding experiment (155 days). These fish were also weighed and tissues taken from individual fish every 30 days. One individual died during the course of the fooddeprivation, so we had a final sample size of five for the negative controls.

At the end of trial two the fish were euthanized in buffered water containing MS-222 (1 $\left.\mathrm{gl}^{-1}\right)$, measured [standard length (SL)], and weighed [body mass (BM)]. Epaxial white muscle samples were taken from each fish for endpoint stable isotopic measurements. The livers of all of the fish were weighed, the hepato-somatic index [HSI=liver mass $(\mathrm{g}) /$ body mass $(\mathrm{g})]$ determined, and a subsample of the liver tissue was dried at $60^{\circ} \mathrm{C}$ and analyzed for $\% \mathrm{C}$ and $\% \mathrm{~N}$ in a Carlo-Erba elemental analyzer. The HSI and $\% \mathrm{C}: \% \mathrm{~N}$ ratio were used to assess the nutritional status of the fish on the different diets (or deprived of food). The HSI is a body condition index (lower HSI=lower body condition, worse nutritional status; Lloret and Planes 2003) and the $\% \mathrm{C}: \% \mathrm{~N}$ ratio indicated whether the fish were mobilizing nitrogen from their livers (higher $\% \mathrm{C}$ : $\% \mathrm{~N}$ ratio=less nitrogen; Karasov and Martínez del Rio 2007), which could indicate that the fish were in negative nitrogen balance. 
Stable isotopic profiles of wild-caught fish and resources

In an attempt to characterize a small portion of the foodweb in Wekiva Springs, FL (see above under "Fish collection and maintenance in the laboratory"), periphyton, coarse benthic organic matter (including large woody debris), predominant invertebrate taxa and fish were collected from the field for stable isotopic measurements (Table 2). Wood, algae, and invertebrates were rinsed with deionized water and frozen in liquid nitrogen in the field. Blood and fin clip samples were taken from fish as described above under "Tissues used for stable isotope analysis". We also collected muscle samples from three fish species that were too small from which to draw a blood sample (because of the needle gauge we used) or take fin clips without killing the fish (Table 2). All tissues and resources were frozen in liquid nitrogen in the field and transported (frozen) to the University of Florida, dried at $60^{\circ} \mathrm{C}$, and stored in sealed containers at room temperature until analyzed.

Woody debris and detritus in general contain an array of carbon compounds, including cellulose, hemicellulose, and lignin (Berg and McClaugherty 2008). The products released during microbial degradation of cellulose and hemicellulose are sugars, and thus, are largely metabolizable by detritivorous fishes, including $P$. disjunctivus (German et al. 2010). Lignin, on the other hand, is composed of diverse monomers, including guiacyl, syringyl, and 4hydroxyphenyl units (Berg and McClaugherty 2008), which may not be metabolizable by fishes, or vertebrates in general (Karasov and Martínez del Rio 2007). Therefore, from an isotopic standpoint, detritivorous fishes are not likely assimilating carbon from lignin in wood or detritus. Conveniently, cellulose and hemicellulose tend to be $2 \%$ enriched in $\delta^{13} \mathrm{C}$ in comparison to bulk wood, whereas lignin tends to be $\sim 4 \%$ depleted relative to bulk wood (Gaudinski et al. 2005; Bowling et al. 2008). Thus, differential assimilation of $\mathrm{C}$ from cellulose and/or lignin is possible to detect with stable isotopes. To examine whether $P$. disjunctivus could assimilate cellulosic and hemicellulosic carbon from wood, holo-cellulose (Leavitt and Danzer 1993; Gaudinski et al. 2005), which comprises the cellulosic and hemicellulosic compounds of wood, was extracted following a slightly
Table 2 Taxa collected from Wekiva Springs, Florida and their stable isotopic signatures

Values are mean $( \pm$ SEM)

${ }^{\mathrm{a}}$ Isotopes measured in lipid extracted muscle tissue of molluscs, crustaceans, and small fishes ( $G$. holbrooki, Lucania goodei, H. Formosa), and lipid extracted fin clips from larger fishes

${ }^{\mathrm{b}}$ Williams and Trexler (2006)

${ }^{\mathrm{c}}$ Masagounder et al. (2009)

${ }^{\mathrm{d}}$ Etnier and Starnes (1993)

e Taylor et al. (2001)

${ }^{\mathrm{f}}$ Belk and Lydeard (1994)

${ }^{\mathrm{g}}$ German (2009b)

\begin{tabular}{|c|c|c|c|c|}
\hline Taxa & Diet & $\mathrm{N}$ & $\delta^{13} \mathrm{C}(\%)$ & $\delta^{15} \mathrm{~N}(\%)$ \\
\hline \multicolumn{5}{|l|}{ Plant/detrital material } \\
\hline Duckweed & - & 4 & $-30.45 \pm 0.22$ & $18.91 \pm 0.21$ \\
\hline Lily pads & - & 4 & $-26.51 \pm 0.10$ & $13.24 \pm 0.13$ \\
\hline Periphyton & - & 4 & $-29.26 \pm 0.25$ & $7.81 \pm 0.31$ \\
\hline Coarse Benthic Organic Matter & - & 4 & $-29.23 \pm 0.43$ & $3.43 \pm 0.29$ \\
\hline Woody debris & - & 4 & $-25.24 \pm 0.11$ & $2.01 \pm 0.20$ \\
\hline Cellulose (extracted from wood) & - & 4 & $-24.09 \pm 0.23$ & N/A \\
\hline \multicolumn{5}{|l|}{ Mollusca } \\
\hline Snail $^{\mathrm{a}}$ & Grazer? & 3 & $-28.83 \pm 0.15$ & $20.70 \pm 0.05$ \\
\hline \multicolumn{5}{|l|}{ Crustacea } \\
\hline Crayfish $^{\mathrm{a}}$ & Shredder & 3 & $-29.46 \pm 0.21$ & $19.58 \pm 0.35$ \\
\hline \multicolumn{5}{|l|}{ Fishes $^{\mathrm{a}}$} \\
\hline Lepisosteus platyrhincus (Florida Gar) & Fish $^{\mathrm{b}}$ & 2 & $-29.22 \pm 0.17$ & $15.00 \pm 0.31$ \\
\hline Micropterus salmoides (Bass) & Fish $^{\mathrm{c}}$ & 2 & $-27.27 \pm 0.82$ & $20.31 \pm 0.40$ \\
\hline Lepomis punctatus (Spotted sunfish) & Invertebrates ${ }^{\mathrm{d}}$ & 3 & $-26.72 \pm 0.48$ & $18.56 \pm 1.75$ \\
\hline L. macrochirus (Bluegill sunfish) & Invertebrates ${ }^{\mathrm{c}}$ & 3 & $-25.96 \pm 0.92$ & $16.46 \pm 1.77$ \\
\hline Gambusia holbrooki (Mosquito fish) & Invertebrates/fish ${ }^{\mathrm{e}}$ & 3 & $-25.07 \pm 0.29$ & $24.24 \pm 0.38$ \\
\hline Lucania goodei (Bluefin killifish) & Invertebrates $^{\mathrm{e}}$ & 3 & $-30.36 \pm 1.51$ & $22.13 \pm 1.02$ \\
\hline Heterandria formosa (Least killifish) & Invertebrates $^{\mathrm{f}}$ & 3 & $-29.02 \pm 0.48$ & $21.51 \pm 0.33$ \\
\hline Pterygoplichthys disjunctivus & Algae/Detritus ${ }^{\mathrm{g}}$ & 9 & $-28.62 \pm 0.65$ & $11.51 \pm 0.42$ \\
\hline
\end{tabular}


modified Jayme-Wise method (Leavitt and Danzer 1993), essentially as described by Gaudinski et al. (2005). Wood was dried at $60^{\circ} \mathrm{C}$, ground to pass through a $1-\mathrm{mm}$ screen, and $200-500 \mathrm{mg}$ samples of the ground wood were placed in polyester solvent bags (Ankom Technology, Macedon, New York). The samples were then extracted in 2:1 Toluene:Ethanol in a Dionex Accelerated Solvent Extractor, followed by a second extraction in $100 \%$ ethanol. The samples were then boiled for $4 \mathrm{~h}$ in deionized water to remove soluble components, and allowed to dry in a drying chamber at room temperature. The bags (containing the samples) were then soaked in 1-L of an aqueous bleach solution containing $10 \mathrm{~g}$ of sodium chlorite and $6 \mathrm{~mL}$ of glacial acetic acid at $70^{\circ} \mathrm{C}$ for 5 days. The bleach/acetic acid solution was changed every $12 \mathrm{~h}$. Following the bleaching, the samples were thoroughly rinsed in running deionized water for $3 \mathrm{~h}$, and dried at $60^{\circ} \mathrm{C}$. The remaining white fibrous material was holo-cellulose as determined by Gaudinski et al. (2005).

\section{Sample preparation for mass spectrometry}

Blood (plasma solutes and RBCs), fin clip samples, and, wood, holo-cellulose, periphyton, and invertebrate samples from the environment, were dried to a constant weight for $24-48 \mathrm{~h}$ at $60^{\circ} \mathrm{C}$ (Reich et al. 2008). Lipids were extracted from all animal and plant samples (except the RBCs and plasma solutes, which were too small) with petroleum ether in a Dionex Accelerated Solvent Extractor (Reich et al. 2008). Animal, plant, or detrital material was loaded into pre-cleaned tin capsules, combusted in a COSTECH ECS 4010 elemental analyzer interfaced via a Finnigan-MAT ConFlow III device (Finnigan MAT, Bremen, Germany) to a Finnigan-MAT DeltaPlus XL (Bremen, Germany) isotope ratio mass spectrometer in the light stable isotope laboratory at the University of Florida, Gainesville, FL, USA. Stable isotope abundances are expressed in delta $(\delta)$, defined as parts per thousand $(\%)$ relative to the standard as follows:

$\delta=\left[\left(\mathrm{R}_{\text {sample }} / \mathrm{R}_{\text {standard }}\right)-1\right](1000)$

where $\mathrm{R}_{\text {sample }}$ and $\mathrm{R}_{\text {standard }}$ are the corresponding ratios of heavy to light isotopes $\left({ }^{13} \mathrm{C} /{ }^{12} \mathrm{C}\right.$ and $\left.{ }^{15} \mathrm{~N} /{ }^{14} \mathrm{~N}\right)$ in the sample and standard, respectively. $\mathrm{R}_{\text {standard }}$ for ${ }^{13} \mathrm{C}$ was Vienna Pee Dee Belemnite (VPDB) limestone formation international standard. $\mathrm{R}_{\text {standard }}$ for ${ }^{15} \mathrm{~N}$ was atmospheric $\mathrm{N}_{2}$. IAEA CH-6 $\left(\delta^{13} \mathrm{C}=-10.4\right)$ and IAEA N1 Ammonium Sulfate $\left(\delta^{15} N=+0.4\right)$, calibrated monthly to VPDB and atmospheric $\mathrm{N}_{2}$, respectively, were inserted in all runs at regular intervals to calibrate the system and assess drift over time. The analytical accuracy of our measurements, measured as the SD of replicates of standards, was 0.14 for $\delta^{13} \mathrm{C}$ and 0.11 for $\delta^{15} \mathrm{~N}(N=120)$.

\section{Statistical analyses}

We estimated growth rates [proportional body mass (g) change day $^{-1}$ ] using an exponential model ( $\mathrm{y}=$ $\mathrm{ae}^{\mathrm{bt}}$; Reich et al. 2008). The fractional rate of isotopic incorporation, $\lambda$, was estimated (in days ${ }^{-1}$ ) with a non-linear fitting procedure using the equation:

$\delta \mathrm{X}(t)=\delta \mathrm{X}(\infty)+[\delta \mathrm{X}(0)-\delta \mathrm{X}(\infty)] \mathrm{e}^{-\lambda t}$,

where $\delta \mathrm{X}(\mathrm{t})$ is the isotopic composition at time $t, \delta \mathrm{X}$ $(\infty)$ is the asymptotic, equilibrium isotopic composition, $\delta \mathrm{X}(0)$ is the initial isotopic composition, and $\lambda$ is the fractional rate of isotope incorporation in a tissue (Martínez del Rio and Wolf 2005; Reich et al. 2008). $\delta \mathrm{X}(\infty)$ and $\delta \mathrm{X}(0)$ were estimated using the same nonlinear procedure. Isotopic discrimination factors $\left(\Delta X_{\text {tissue-diet }}\right)$ were calculated as $\delta X_{\text {tissue }}-\delta X_{\text {diet }}$. Turnover times (average residence times) of $\mathrm{C}$ and $\mathrm{N}$ molecules in trial one were calculated as $1 / \lambda$ (Reich et al. 2008). $\lambda$ can be defined as the sum of tissue net growth $\left(\mathrm{k}_{\mathrm{gt}}\right)$ and tissue catabolic turnover $\left(\mathrm{k}_{\mathrm{dt}}\right)$; thus, $\lambda=\mathrm{k}_{\mathrm{gt}}+\mathrm{k}_{\mathrm{dt}}$. If an animal, and hence, its tissues, is growing exponentially, then one can measure growth and determine the contribution of growth and tissue catabolic turnover to $\lambda$ (Hesslein et al. 1993; MacAvoy et al. 2001; Jardine et al. 2004; Sakano et al. 2005; Suzuki et al. 2005; Guelinckx et al. 2007; Vollaire et al. 2007; Zuanon et al. 2007; Reich et al. 2008). Following Reich et al. (2008), we assumed that the fractional growth rate of a tissue was equal to the fractional rate of growth of the whole animal $\left(\mathrm{k}_{\mathrm{g}}\right)$. We then compared $\lambda$ to $\mathrm{k}_{\mathrm{g}}$ using $t$-tests; a large difference between $\lambda$ and $k_{\mathrm{g}}$ indicates a large contribution of tissue catabolic turnover to isotopic incorporation as opposed to new tissue accretion. Because we used adult animals in our experiments, we anticipated large differences between $\lambda$ and $k_{\mathrm{g}}$, and thus, significant contributions of catabolic turnover, unlike growing juvenile animals (Trueman et al. 2005; GamboaDelgado et al. 2008; Reich et al. 2008). 
Because single compartment models can oversimplify the isotopic incorporation process in tissues, we also used two compartment models to analyze our isotopic incorporation data (Carleton et al. 2008). We used the Akaike's Information Criterion (AIC) to analyze the support of the different models and evaluate which models more appropriately fit our data (Carleton et al. 2008). For plasma solutes and RBCs, the AIC values were lower for the one compartment models (34.73 to 46.41) than for the two compartment models (41.51 to 53.25), indicating that one compartment models were appropriate in our data analysis (Carleton et al. 2008).

In trial two, we used the following concentrationdependent linear mixing model incorporating digestibility estimates to predict the final isotopic signatures of the fish if they were assimilating the entire wooddetritus diet:

$\mathrm{p}_{\mathrm{xi}}=\frac{e_{i} p_{i} x_{i}}{\sum_{j=1}^{n} e_{x_{j}} p_{j} x_{j}}$

where $p_{x i}$ is the expected isotopic signature assimilated of element $\mathrm{X}, \mathrm{e}_{\mathrm{i}}$ is the digestibility coefficient for an element in a dietary ingredient (e.g., wood), $p_{i}$ is the proportion of the diet composed of that ingredient, $x_{i}$ is the concentration (\%) of the element in question (e.g., C) in the ingredient, and the denominator is the summed totals of all of the ingredients in the diet (Martínez del Rio and Wolf 2005). The $e_{i}$ for element $X$ in each ingredient was assumed to be equal to the digestibility coefficient of the ingredient as a whole. Digestibility estimates for wood and cellulose were garnered (for P. disjunctivus specifically) from German (2009b) and digestibilities for corn gluten meal (Guimarães et al. 2008) and corn meal (Krogdahl et al. 2005) were taken from the literature for detritivorous Nile tilapia (Oreochromis niloticus). Xanthan gum was considered an indigestible non-starch polysaccharide (Leenhouwers et al. 2006), and the vitamins and minerals were considered $100 \%$ absorbable. With these ingredients and digestibilties, the artificial wood-detritus diet had the following predicted digestible isotopic signature: $\delta^{13} \mathrm{C}=-21.03 \%$, and $\delta^{15} \mathrm{~N}=3.25 \%$. Thus, the expectation would be that the fish would reach this isotopic signature by the end of the feeding trial. Deviations from this value could indicate differential assimilation of different dietary components.
Because we were not exhaustive in resource collection, we did not employ a mixing model to estimate the diet of the wild-caught fish. Instead, we relied upon discrimination factors from Trial one, those predicted by equations designed for fish (Caut et al. 2009), and gut content analyses (German 2009b) to make inferences about the isotopic signatures of wild-caught $P$. disjunctivus.

Hepato-somatic indices and liver $\% \mathrm{C}: \% \mathrm{~N}$ ratios were compared among the experimental (wood-detritus diet), control (algae diet), and food-deprived groups with Analysis of Covariance (ANCOVA; using body mass as a covariate), followed by a Tukey's test with a family error rate of $\mathrm{P}=0.05$. Prior to all $t$-tests and ANCOVA, a Levene's test for equal variance was performed to ensure the appropriateness of parametric analyses. All statistics were run with SPSS statistical software (version 12).

\section{Results}

Trial one: initial turnover

The exponential growth rate for algae-fed fish was (mean \pm SD) $0.0017 \pm 0.0006 \mathrm{day}^{-1}$, and the fish gained $40.86 \pm 0.17 \%$ of their body mass during the experiment. The exponential model $\left(y=a e^{b t}\right)$ described the growth rates of the fish reasonably well $\left(\mathrm{r}^{2}\right.$ ranged from 0.82-0.99). Equation 2 described the changes in $\delta^{13} \mathrm{C}$ and $\delta^{15} \mathrm{~N}$ through time adequately well for all of the tissues $\left(\mathrm{r}^{2}\right.$ ranged from 0.54 to 0.88 ; Fig. 1). Plasma solutes and RBCs showed isotopic incorporation rates that were significantly greater than those expected by growth alone $\left(0.0017\right.$ day $\left.^{-1}\right)$, indicating a significant contribution of tissue catabolic turnover to isotopic incorporation in these tissues (Table 3). Tissue catabolic turnover contributed between 79 and $94 \%$ of carbon isotopic incorporation, and approximately $98 \%$ of nitrogen incorporation in RBCs and plasma solutes. $\Delta^{13} \mathrm{C}_{\text {tissue-diet }}$ and $\Delta^{15} \mathrm{~N}_{\text {tissue-diet }}$ varied by tissue, with $\Delta^{13} \mathrm{C}_{\text {tissue-diet }}$ ranging from 0.06 to $0.24 \%$, and $\Delta^{15} \mathrm{~N}_{\text {tissue-diet }}$ ranging from 4.39 to $5.17 \%$ (Table 3 ). Fin tissue had similar $\Delta^{15} \mathrm{~N}_{\text {tissue-diet }}(4.08 \%)$ as plasma solutes and RBCs, but the $\Delta^{13} \mathrm{C}_{\text {tissue-diet }}$ for fin tissue $(1.75 \%$ ) was greater than the other tissues (see Supplemental Fig. S1 in the online version of this article). The residence times of $\mathrm{C}$ varied between 33 days in plasma solutes and 128 days in RBCs (Table 3). Nitrogen turnover times varied from 11 days 

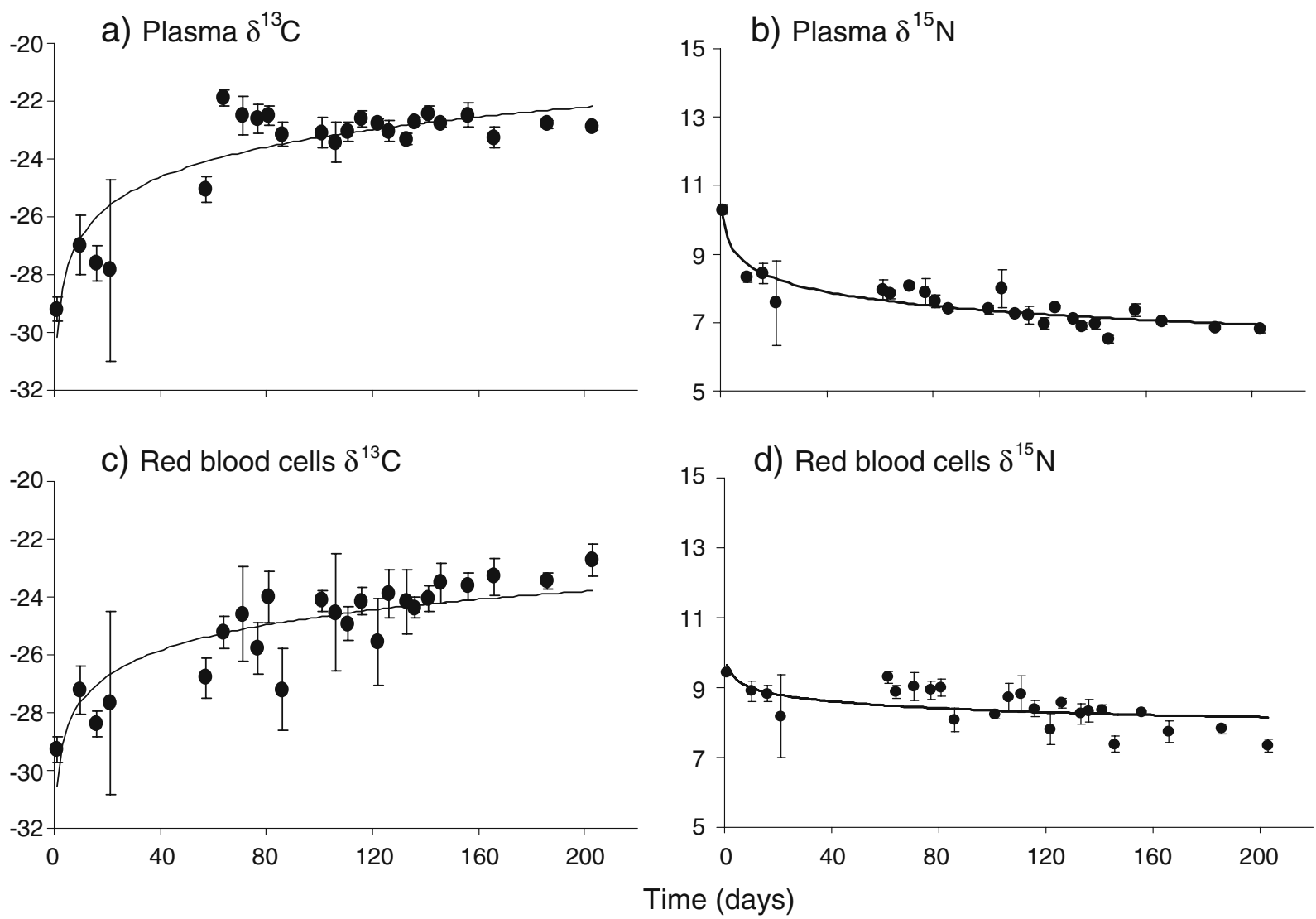

Fig. 1 Changes in $\delta^{13} \mathrm{C}$ and $\delta^{15} \mathrm{~N}$ (\%) in Pterygoplichthys disjunctivus 0-203 days after a diet switch. Values are mean $[ \pm$ standard error of the mean (SEM)]. Curves were fit by a

nonlinear routine with the equation $\delta \mathrm{X}(\mathrm{t})=\delta \mathrm{X}(\infty)+[\delta \mathrm{X}(0)-$ $\delta \mathrm{X}(\infty)] \mathrm{e}^{-\lambda \mathrm{t}}$ (see "Statistical analyses")

in plasma solutes to 14 days in RBCs (Table 3). Fin tissue from the first 29 days of the experiment showed rapid turnover of ${ }^{13} \mathrm{C}$ and ${ }^{15} \mathrm{~N}$ (Supplemental Fig. S1).

Trial two: assimilation of wood-detritus and negative control

All of the fish lost body mass on the artificial wood-detritus diet, with the mean loss being $7.87 \pm$ $2.74 \%$ of their body mass over 155 days, whereas the control fish on the algae diet gained $31.23 \pm$ $8.10 \%$ of their body mass over the same time period. The food-deprived fish lost $3.67 \pm 1.49 \%$ of their body mass over 155 days. The fish on the artificial wood-detritus diet lost significantly more weight than those that were food-deprived ( $t=$ 10.61, $P<0.001$, d.f.=9), likely because the former were more active on a daily basis than the latter (DPG, pers. obs.), and because the food-deprived

fish were significantly larger than the wood-fed fish (German et al. 2010). Equation 2 adequately described the changes in $\delta^{13} \mathrm{C}$ over time for plasma solutes, but less so for RBCs (Table 4; Fig. 2). A linear procedure was necessary to describe the incorporation of $\delta^{13} \mathrm{C}$ for the fin clip samples. Equation 2 appropriately described the incorporation of $\delta^{15} \mathrm{~N}$ over time in plasma solutes and fin clips, but not for RBCs, which required a linear procedure (Table 4; Fig. 2). The $\delta^{13} \mathrm{C}$ of all tissues became enriched over the course of the experiment, moving toward the predicted signature (Table 4). The $\delta^{13} \mathrm{C}$ values of control fish (i.e., those consuming the algal diet) were unchanging over the course of the experiment (Fig. 2). The isotopic incorporation for plasma solute $\delta^{13} \mathrm{C}$ in trial one was similar to that observed in trial two for the fish consuming the artificial wood-detritus $\left(0.030\right.$ and 0.023 day $^{-1}$, respectively; Tables 3 and 4, respectively). 
Table 3 The incorporation of carbon and nitrogen from an algal diet (trial one) into tissues of Pterygoplichthys disjunctivus using the equation: $\delta \mathrm{X}(\mathrm{t})=\delta \mathrm{X}(\infty)+[\delta \mathrm{X}(0)-\delta \mathrm{X}(\infty)] \mathrm{e}^{-\lambda \mathrm{t}}$

\begin{tabular}{|c|c|c|c|c|}
\hline Tissue & Equation & $\Delta \mathrm{X}_{\text {tissue-diet }}$ & $\lambda$ vs. $\mathrm{k}_{g t}$ & Average residence time (days) \\
\hline \multicolumn{5}{|l|}{$\delta^{13} \mathrm{C}$} \\
\hline Plasma solutes & $-22.65-7.09 \mathrm{e}^{-0.030(\text { time })}$ & $0.06 \pm 0.08$ & $72.85^{*}$ & $32.95 \pm 6.53$ \\
\hline $\begin{array}{l}\text { Red blood cells } \\
\delta^{15} \mathrm{~N}\end{array}$ & $-21.62-7.13 \mathrm{e}^{-0.008(\text { time })}$ & $0.24 \pm 0.56$ & $16.64^{*}$ & $127.78 \pm 10.21$ \\
\hline Plasma solutes & $7.31+3.20 \mathrm{e}^{-0.091 \text { (time) }}$ & $4.39 \pm 0.05^{\mathrm{a}}$ & $34.01 *$ & $11.05 \pm 0.33$ \\
\hline Red blood cells & $8.30+1.21 \mathrm{e}^{-0.073 \text { (time) }}$ & $5.17 \pm 0.13^{\mathrm{a}}$ & $12.86^{*}$ & $13.98 \pm 1.17$ \\
\hline
\end{tabular}

$\Delta X_{\text {tissue-diet }}$ is the mean $( \pm \mathrm{SE})$ tissue-diet discrimination factor for each tissue

a indicates significant difference from 0 with 1 -sample $t$-test $(P<0.001)$

*indicate significant differences $(P<0.001)$ as determined with $t$-tests between the fractional rate of isotopic incorporation $(\lambda)$ and the growth rate $(\mathrm{kgt}=0.0017$ day-1) for plasma solutes and $\mathrm{RBCs}$

Average residence $( \pm \mathrm{SEM})$ time was estimated as $1 / \lambda$

Different patterns of plasma ${ }^{13} \mathrm{C}$ incorporation were observed between the fishes consuming the artificial wood-detritus and those that were deprived of food (Fig. 3). Whereas the ${ }^{13} \mathrm{C}$ incorporation in plasma solutes was described by Eq. 2 for the fish consuming the artificial wood-detritus (Table 4), a polynomial distribution described the pattern of $\mathrm{C}$ incorporation in the food-deprived fish (Fig. 3). These differences are likely the result of the assimilation of the soluble components from the artificial wood-detritus diet.
The patterns of plasma ${ }^{15} \mathrm{~N}$ incorporation were similar between the fish consuming the artificial wood-detritus and those that were deprived of food (Fig. 3)-both were described by Eq. 2 (Table 4), and the equation for the food-deprived fish was 11.26$2.28 \mathrm{e}^{-0.005(\text { time })}\left(\mathrm{r}^{2}=0.98\right)$. The fractional rate of nitrogen incorporation $\left(0.005\right.$ day $\left.^{-1}\right)$ was identical in the two groups. The loss of weight and the pattern of plasma $\mathrm{N}$ incorporation in the fish consuming the artificial wood-detritus indicate that these fish were in

Table 4 The incorporation of carbon and nitrogen from an artificial wood-detritus diet (trial two) into tissues of Pterygoplichthys disjunctivus

\begin{tabular}{|c|c|c|c|}
\hline Tissue & Equation $^{\mathrm{a}}$ & $r^{2}$ & $\delta \mathrm{X}_{\text {tissue }}($ final $)-\delta \mathrm{X}_{\text {diet }}(\text { final })_{\text {predicted }} \mathrm{b}$ \\
\hline \multicolumn{4}{|l|}{$\delta^{13} \mathrm{C}$} \\
\hline Plasma solutes & $-21.16-1.83 \mathrm{e}^{-0.023(\mathrm{time})}$ & 0.71 & -0.07 \\
\hline Red blood cells & $-20.17-2.52 \mathrm{e}^{-0.002(\mathrm{time})}$ & 0.48 & -0.91 \\
\hline $\begin{array}{l}\text { Fin clips } \\
\delta^{15} \mathrm{~N}\end{array}$ & 0.014 (time) -20.72 & 0.87 & -0.93 \\
\hline Plasma solutes & $10.12-3.03 \mathrm{e}^{-0.005(\text { time })}$ & 0.83 & 0.79 \\
\hline Red blood cells & 0.011 (time) $)+7.21$ & 0.82 & -0.64 \\
\hline Fin clips & $8.57-2.15 \mathrm{e}^{-0.021(\text { time })}$ & 0.94 & 1.29 \\
\hline
\end{tabular}

${ }^{\mathrm{a}}$ The non-linear procedure using equation $\delta \mathrm{X}(\mathrm{t})=\delta \mathrm{X}(\infty)+[\delta \mathrm{X}(0)-\delta \mathrm{X}(\infty)] \mathrm{e}^{-\lambda \mathrm{t}}$ described the isotopic incorporations of $\delta^{13} \mathrm{C}$ and $\delta^{15} \mathrm{~N}$ in plasma solutes reasonably well. Linear procedures were necessary to describe $\delta^{13} \mathrm{C}$ incorporation in fin tissue and $\delta^{15} \mathrm{~N}$ incorporation in RBCs

${ }^{\mathrm{b}}$ This value represents the difference between the final observed isotopic signature of the tissues at the end of the experiment minus that predicted by a linear, concentration-dependent mixing model (Martínez del Rio and Wolf 2005) for the artificial wood-detritus ingredients, plus the expected $\Delta \mathrm{X}_{\text {tissue-diet }}$ observed in trial one for each tissue; $\delta^{13} \mathrm{C}(\text { final })_{\text {predicted }}=-21.03 \% ; \delta^{15} \mathrm{~N}(\text { final })_{\text {predicted }}=$ $3.25 \%$ 

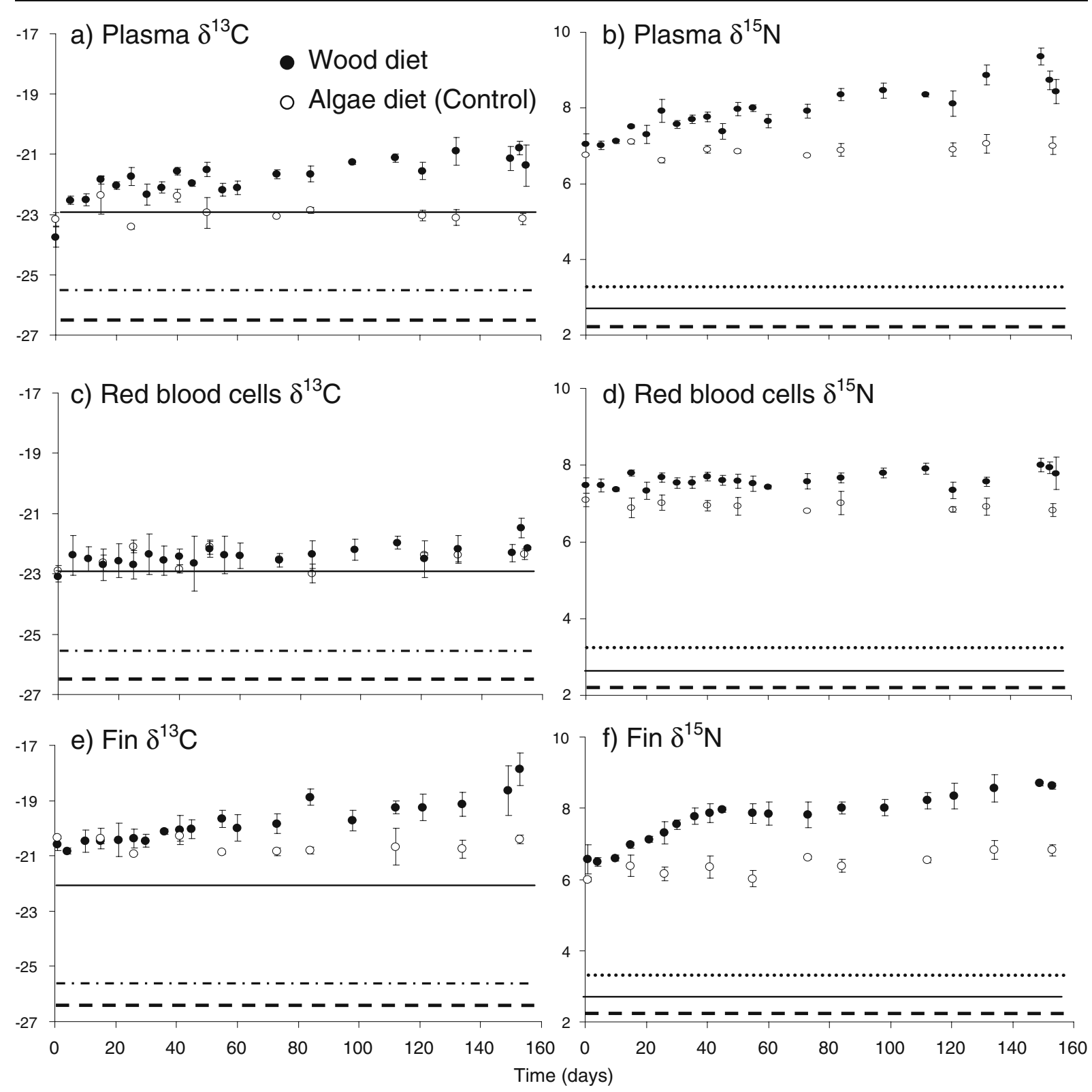

Fig. 2 Changes in $\delta^{13} \mathrm{C}$ and $\delta^{15} \mathrm{~N}$ (\%) in Pterygoplichthys disjunctivus across 155 days while consuming an artificial wood-detritus diet or an algal diet (positive control). Values are mean $\left( \pm\right.$ SEM). The solid lines represent the $\delta^{13} \mathrm{C}$ and $\delta^{15} \mathrm{~N}$ signatures of the algal diet, whereas the dashed line represents the $\delta^{13} \mathrm{C}$ and $\delta^{15} \mathrm{~N}$ signatures of the bulk wood in the artificial wood-detritus diet. In the carbon plots, the dash-dot line represents the $\delta^{13} \mathrm{C}$ of holo-cellulose isolated from the wood.

negative nitrogen balance. This is further corroborated by the hepato-somatic indices of the fish, which were significantly lower in the food-deprived fish and in those consuming the artificial wood-detritus than in
In the nitrogen plots, the dotted line represents the $\delta^{15} \mathrm{~N}$ signature of the corn products representing the soluble component of the artificial wood-detritus diet. Lipids were extracted from the tissues and all ingredients for the fin clip analyses, but not for the plasma and red blood cell analyses. The $\delta^{13} \mathrm{C}$ of the corn products $(-11.82 \%$ ) is off the scale of the carbon plots. Equations for all relationships presented in Table 4

those consuming algae (See Supplemental Fig. S2 in the online version of this article). Protein reserves were probably mobilized in the food-deprived fish, as the $\% \mathrm{C}: \% \mathrm{~N}$ ratio in their liver was significantly 

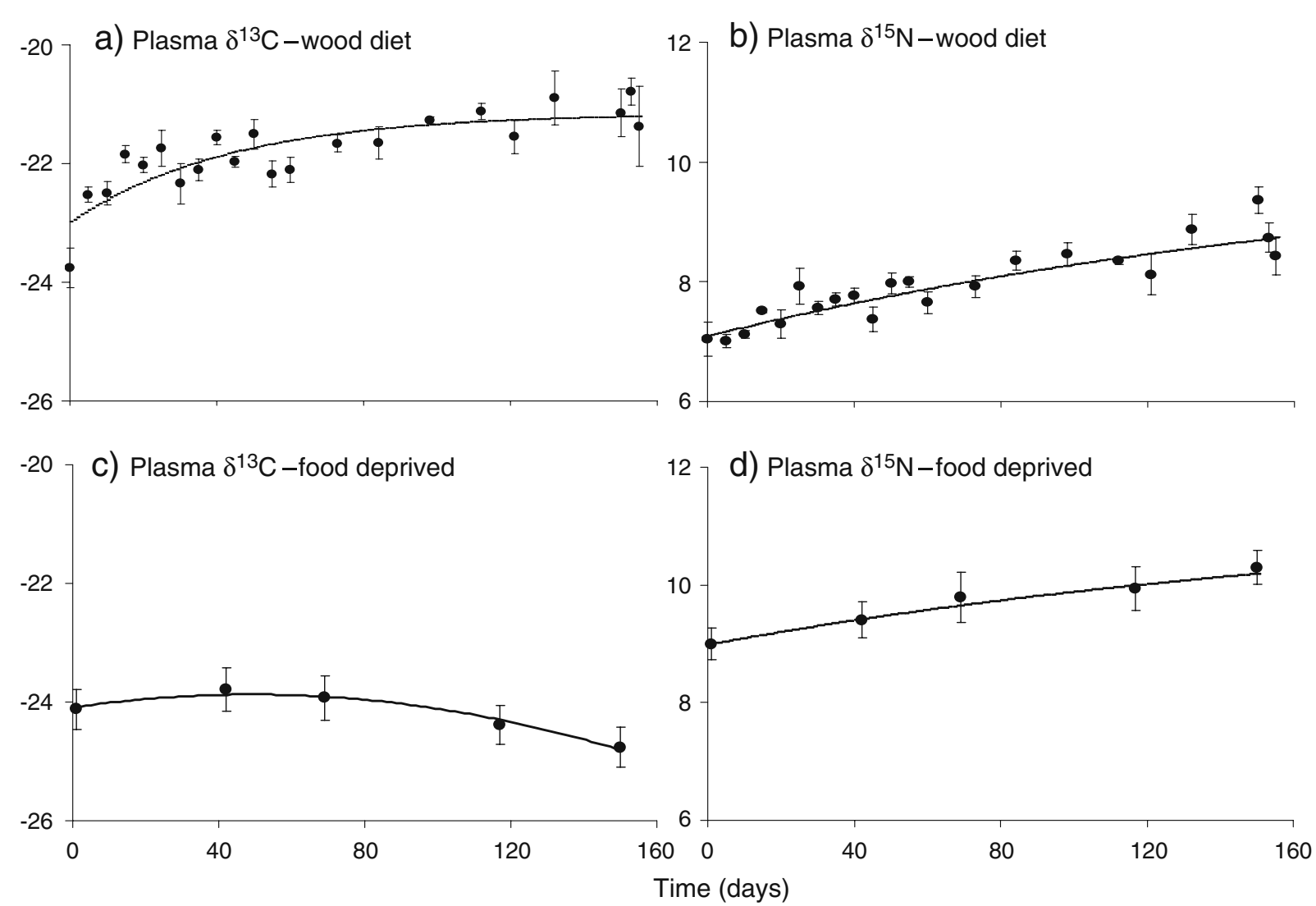

Fig. 3 Changes in $\delta^{13} \mathrm{C}$ and $\delta^{15} \mathrm{~N}$ (\%) in plasma solutes of Pterygoplichthys disjunctivus across 155 days while consuming an artificial wood-detritus diet or those that were deprived of food (negative control). Values are mean $( \pm$ SEM). Curves for the fish consuming the artificial wood-detritus, and the $\delta^{15} \mathrm{~N}$ of the food-

greater than in the algae-fed fish (Supplemental Fig. S2). The $\% \mathrm{C}: \% \mathrm{~N}$ ratios in the livers of the fish consuming the artificial wood-detritus were statistically indistinguishable from either group.

The food deprived fish showed that plasma $\delta^{15} \mathrm{~N}$ signatures become enriched over time (Fig. 3), but at a slow pace $\left(0.005 \mathrm{~d}^{-1}\right)$, resulting in a significant change (in comparison to starting values) only after 155 days of food deprivation (Dunnett's test, $\mathrm{p}=$ 0.032). Plasma $\delta^{13} \mathrm{C}$ values did not differ significantly from starting values at any point (ANOVA $\mathrm{F}_{4,24}=$ $1.25 ; \mathrm{P}=0.32$ ), and neither did the $\delta^{15} \mathrm{~N}$ (ANOVA $\mathrm{F}_{4,24}=0.01 ; \mathrm{P}=1.00$ ) or $\delta^{13} \mathrm{C}$ values (ANOVA $\mathrm{F}_{4,24}=$ $0.16 ; \mathrm{P}=0.95)$ of $\mathrm{RBCs}$.

The control fish consuming the algae diet for nearly 400 days had the following final isotopic signatures in their muscle tissue: $\delta^{13} \mathrm{C}=-22.03 \pm$ $0.21 \%$ o, $\delta^{15} \mathrm{~N}=7.39 \pm 0.16 \%$ o, $\Delta{ }^{13} \mathrm{C}_{\text {tissue-diet }}=-0.01 \%$, deprived fish were fit with the equation $\delta \mathrm{X}(t)=\delta \mathrm{X}(\infty)+[\delta \mathrm{X}(0)-$ $\delta \mathrm{X}(\infty)] \mathrm{e}^{-\lambda t}$, whereas the $\delta^{13} \mathrm{C}$ of the food-deprived fish was best fit by a polynomial distribution $\left(y=0.00009 x^{2}+0.009 x-24.09\right.$; $\left.r^{2}=0.97\right)$

$\Delta^{15} \mathrm{~N}_{\text {tissue-diet }}=5.13 \%$. Because of the duration, we believe these isotopic values reflect steady state with the isotopic signature of the algal diet.

Wild-caught fish and resources

Pterygoplichthys disjunctivus is not likely utilizing cellulosic carbon as a food source in Floridian riverine habitats (Fig. 4). This fish had $\delta^{13} \mathrm{C}$ signatures that were more depleted than periphyton or coarse benthic organic matter, although, by assuming a $\Delta^{15} \mathrm{~N}_{\text {tissue-diet }}$ of $4-5 \%$, as observed in trial one, these fish may be getting some nitrogen from periphyton sources, consistent with gut content analyses for this species (German 2009b). Because we were not exhaustive in our resource collection it is difficult to discern the exact carbon sources for $P$. disjunctivus, but we can be confident it is not from 


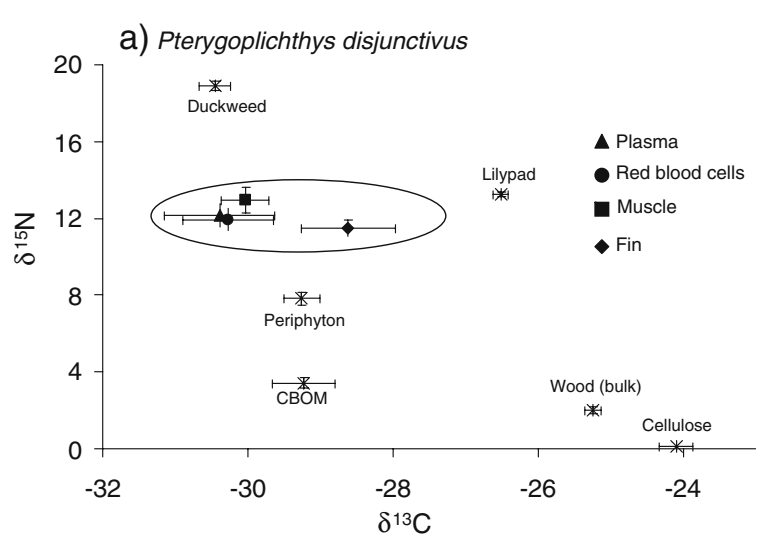

b) $P$. disjunctivus, other animals, and resources

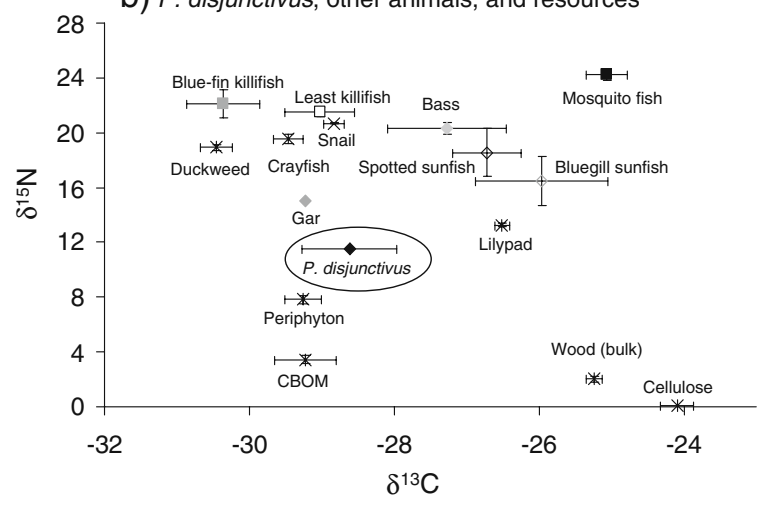

Fig. 4 Carbon and nitrogen (\%o) dual-isotope plots of animals and resources collected from Wekiva Springs, FL, USA in January 2008 - a) shows the different tissues of only Pterygoplichthys disjunctivus and potential resources, b) shows $P$. disjunctivus in addition to other animals. Only lipid-extracted fin tissue (large fish) and muscle tissue (invertebrates and small fish, see Table 3) were used to analyze the isotopic signatures of the animals in plot $\mathrm{b} . \mathrm{CBOM}=$ coarse benthic organic matter

wood or cellulose. When including other animal taxa in the carbon-nitrogen dual-isotope plot, $P$. disjunctivus occupies a lower trophic level than the common fish species in the Floridian spring habitat (Fig. 4).

\section{Discussion}

To our knowledge, this study is one of the first to report on the rates of isotopic incorporation and tissue-diet discrimination factors for plasma solutes and $\mathrm{RBCs}$ in a fish species, and it is the only investigation to report on isotopic incorporation in fish enduring long-term (155 days) food-deprivation under controlled conditions. Fishes and ectotherms in general are less well-studied than mammals and birds in these regards (Seminoff et al. 2007; Reich et al. 2008). Our hypotheses were supported by the results of this study. First, as long as an animal is consuming an adequate diet (i.e., is not losing weight), plasma solutes, RBCs, and fin tissue make appropriate nonlethally sampled tissues to track dietary history with stable isotopes, and incorporate a dietary signal on different time scales. Second, isotopic incorporation appears to be primarily driven by catabolic tissue turnover in slowly growing adult fishes. And third, $P$. disjunctivus cannot assimilate carbon from the fibrous portions of detritus, and, consistent with its digestive physiology (German and Bittong 2009; German et al. 2010), probably does not use recalcitrant polymers (e. g., cellulose) as a resource in the wild.

Plasma solutes incorporated ${ }^{13} \mathrm{C}$ and ${ }^{15} \mathrm{~N}$ more quickly than RBCs in $P$. disjunctivus. The half-lives for $C$ in these tissues (calculated as $\ln (2) / \lambda$ ) ranged from 22 to 87 days, respectively, and from 8 to 10 days, respectively, for N. Differences in turnover rates among tissues are not uncommon in fishes and other animals. For example, MacAvoy et al. (2001) observed half-life values of approximately 170 days for $\mathrm{C}$ and $\mathrm{N}$ in channel catfish (Ictalurus punctatus) muscle and whole blood, whereas half-lives ranged from 24 to 65 days for $\mathrm{N}$ in muscle of sockeye salmon (Oncorhynchus nerka; Sakano et al. 2005). McIntyre and Flecker (2006) estimated half-lives of 17 and 12 days for $\mathrm{N}$ in whole blood and fin, respectively, in the loricariid catfish Ancistrus triradiatus. Japanese temperate bass (Lateolabrax japonicas) fin tissue showed half-life values of 26 and 23 days for $\mathrm{C}$ and N, respectively (Suzuki et al. 2005). Finally, sand goby (Pomatoschistus minutus) muscle and liver exhibited half-lives of 25 and 9 days, respectively, for ${ }^{13} \mathrm{C}$, and 28 and 3 days, respectively, for ${ }^{15} \mathrm{~N}$; (Guelinckx et al. 2007). Thus, the turnover rates observed in $P$. disjunctivus are within the range of other fish tissues, which indicates that the different fractions of blood are alternative, non-lethally sampled tissues for fish stable isotopic studies, especially for threatened species from which muscle cannot be taken. Moreover, our fin isotopic incorporation data concur with previous work (Kelly et al., 2006; Hanisch et al. 2010) suggesting that fins are also appropriate tissues to sample non-lethally from fish (Supplemental Fig. S1).

Most studies of isotopic incorporation in fishes have been performed with juvenile animals that grow 
at a rapid pace (Hesslein et al. 1993; Suzuki et al. 2005; Trueman et al. 2005; Vollaire et al. 2007; Zuanon et al. 2007; Gamboa-Delgado et al. 2008). Thus, in these studies, rates of isotopic incorporation were similar to growth rate and, therefore, mostly reflective of new tissue accretion. In the current study, rates of isotopic incorporation in trial one were significantly greater than the growth rates of the adult fish, potentially indicating a significant contribution of catabolic turnover to isotopic incorporation in adult $P$. disjunctivus. Future studies of isotopic incorporation in animal tissues could use juvenile and adult animals to discern the contributions of growth vs. catabolic tissue turnover at different stages of an animal's life. Such data would be valuable to the stable isotope literature.

Pterygoplichthys disjunctivus lost weight on the artificial wood-detritus diet and was in negative nitrogen balance. The plasma $\delta^{13} \mathrm{C}$ signatures of these fish suggested, however, that they were assimilating carbon from the food; the fish on the artificial wooddetritus diet had rates of plasma carbon isotopic incorporation similar to the fish from trial one with the algal diet, and different from fish deprived of food. The results from trial two suggest that $P$. disjunctivus cannot assimilate refractory polysaccharides from wood. German (2009b) showed that neither P. disjunctivus nor Panaque nigrolineatus (a true wood-eating catfish) could assimilate significant amounts of organic matter $(12.76 \%$ and $11.37 \%$, respectively) or lignocellulose $(32.08 \%$ and $23.69 \%$, respectively) from a strictly wood diet in the laboratory, and both species lost weight when consuming solely wood. This inability to digest cellulose in their GI tracts comes from rapid gut transit $(<4$ h; German 2009b) and low cellulase activities (German and Bittong 2009). However, the fish are efficient at digesting soluble components of detritus (e.g., $\alpha$-glucans, laminarin, $\beta$-glucosides, $\beta$ mannosides; German and Bittong 2009; German et al. 2010). This is further supported by the $C$ incorporation in P. disjunctivus on the artificial wood-detritus, and the similarity between the predicted $\delta^{13} \mathrm{C}$ signature of the artificial wood-detritus diet and the $\delta^{13} \mathrm{C}$ of the fish's tissues.

The predicted isotopic signature for the artificial wood detritus diet was arrived at by assuming (based on published data) low cellulose digestibility and high corn digestibility in the mixing model. Cellulose composed more than $40 \%$ of the artificial wooddetritus diet, whereas the corn composed $\sim 11 \%$ (Table 1). Hence, the similarity between the fish's final plasma solute $\delta^{13} \mathrm{C}$ signature $(-21.38 \%$ ) and that predicted by the mixing model $(-21.03 \%)$ provide more evidence that $P$. disjunctivus cannot efficiently assimilate cellulose, but does efficiently digest soluble components from a detrital diet. If $P$. disjunctivus assimilated significant amounts of $\mathrm{C}$ from cellulose, the isotopic signature of their plasma solutes would have been closer to the isotopic signature of cellulose $(-25.39 \%)$ in the laboratory and in nature, which was not observed.

The fish consuming the artificial wood-detritus were in negative nitrogen balance, similar to the fooddeprived fish, even though the diet of the former contained corn gluten meal, which is $70 \%$ protein and known to be a highly-digestible protein source for detritivorous fishes (e.g., Nile tilapia; Guimarães et al. 2008). We also supplemented the artificial wooddetritus with L-lysine to account for a deficiency of this amino acid in corn gluten meal (Guimarães et al. 2008). The artificial wood-detritus may have been lower in quality than we intended, and/or we may not have allowed the fish to consume enough of the diet to meet their nitrogen needs. This is despite the point that we offered the fish $8 \%$ of their body mass of the artificial wood-detritus diet on a daily basis, an amount we considered ad libitum (German et al. 2010). Perhaps this amount is not reflective of the amount of food the fish are capable of eating, and need to consume, to meet their energetic and nitrogen requirements. Moreover, corn gluten meal, although appropriate for tilapia, which possess an acidic stomach, may not be digested as efficiently by $P$. disjunctivus, which lacks a gastric stomach (da Cruz et al. 2009; German 2009b).

The $\Delta^{13} \mathrm{C}_{\text {tissue-diet }}$ values observed in trial one of this study varied by tissue, but were relatively consistent with discrimination factors reported for different tissues in the literature (Reich et al. 2008). The $\Delta^{15} \mathrm{~N}_{\text {tissue-diet }}$ values observed in P. disjunctivus tissues $(4.08 \%$ in fin tissue to $5.17 \%$ o in RBCs; Table 3; Fig. S1) were higher than the widely used average of 3.4\% for this isotope for muscle tissue (Fry and Sherr 1984; Focken 2004; Fry 2007), but were not inconsistent with $\Delta^{15} \mathrm{~N}_{\text {tissue-diet }}(>4 \%$ ) in herbivorous mammals (Robbins et al. 2005) or fishes (Mill et al. 2007). The major contributing factors to 
$\Delta^{15} \mathrm{~N}_{\text {tissue-diet }}$ are growth rate, dietary protein content, protein quality (i.e., the biological value, or how well the amino acid profile of the dietary protein meets the needs of the animal; Robbins et al. 2005; Robbins et al. 2010), and the dietary $\delta^{15} \mathrm{~N}$ (Caut et al. 2009; Martínez del Rio et al. 2009). Herbivorous animals generally consume protein that is low-quality, and/or has low $\delta^{15} \mathrm{~N}$ (Robbins et al. 2005), and hence, herbivorous animals have larger $\Delta^{15} \mathrm{~N}_{\text {tissue-diet }}$ than carnivores. The algal diet was approximately $32 \%$ protein $(5.82 \% \mathrm{~N})$, but this protein was entirely from plant and algal sources (which may make it low in biological value), and the $\delta^{15} \mathrm{~N}$ of the food was $2.43 \%$. According to the regression equations produced for fish tissues by Caut et al. (2009), a fish consuming a diet with this isotopic signature should have $\Delta^{15} \mathrm{~N}_{\text {tissue-diet values of } 5.20 \% \text { o for muscle and }}$ $4.26 \%$ for other tissues. These predicted values are similar to the observed $\Delta^{15} \mathrm{~N}_{\text {tissue-diet }}$ values of 5.13\%o for muscle and $4.39 \%$ for plasma solutes in $P$. disjunctivus from trial one.

Based on the isotopic turnover rates and tissue-diet discrimination factors observed in trial one, it is possible to evaluate the trophic standing of wildcaught $P$. disjunctivus. This fish species is feeding at a lower trophic level than other fishes in Florida spring habitats, at least on the collection date. Gut content analyses of $P$. disjunctivus suggest they consume $40 \%$ detritus, $23 \%$ diatoms, $22 \%$ green algae, $10 \%$ sediment, and 5\% animal material (German 2009b). Green algae (Evans-White et al. 2001) and diatoms (Nichols and Garling 2000) can individually be more depleted in $\delta^{13} \mathrm{C}(<-30 \%)$ than the signature observed for periphyton $(-29.26 \%$ ) in this study, which may explain the depleted $\delta^{13} \mathrm{C}(-30.3 \%)$ observed in wild-caught $P$. disjunctivus. Furthermore, we do not know the isotopic signature of fine benthic organic matter (amorphous detritus) in the Wekiva Springs complex and Wekiva River, and hence, we did not use a mixing model to predict the isotopic signature of wild-caught $P$. disjunctivus tissues. However, based on $\Delta^{15} \mathrm{~N}_{\text {tissue-diet }}$ values observed in the laboratory, $P$. disjunctivus has $\delta^{15} \mathrm{~N}$ values consistent with periphyton as a source of protein. Periphyton can be rich in soluble polysaccharides (Leppard 1995; Wotton 2004; Klock et al. 2007), lipids (Napolitano et al. 1996), and protein (Bowen et al. 1995), and thus, may be a relatively nutritious food source for grazing fishes (German 2009a). The similarity in isotopic signature among all of the tissues sampled from wild-caught $P$. disjunctivus suggests that this fish species has a relatively consistent diet over time in Wekiva springs, or at least in the time period leading up to tissue collection.

The effects of food deprivation on the isotopic signatures of fish tissues are poorly understood. It has been hypothesized that food-deprived animals catabolize their own tissues for energy and maintenance, and hence, become more enriched in ${ }^{15} \mathrm{~N}$ over time (McCue and Pollock 2008; Martínez del Rio et al. 2009). In support of this, carp fed a ration sufficient only for body mass maintenance for 56 days showed a $0.5 \%$ increase in whole body $\delta^{15} \mathrm{~N}$ in comparison to starting values (Gaye-Siessegger et al. 2004). Additionally, salmon at the end of migration $(\sim 133$ days without feeding) had liver $\delta^{15} \mathrm{~N}$ values that were $1.5 \%$ enriched in comparison to the beginning of migration (Doucett et al. 1999). Similarly, we found that plasma solute $\delta^{15} \mathrm{~N}$ values became enriched $1.3 \%$ in food-deprived $P$. disjunctivus. The mechanisms behind the $\delta^{15} \mathrm{~N}$ increase in food-deprived animals require further study (Martínez del Rio et al. 2009).

In conclusion, this study is one of the first to show that fractions of blood-plasma solutes and RBCscan be used as non-lethally sampled tissues for stable isotopic analyses in fish, and is one of a few to estimate isotopic turnover rates of fin tissue (Suzuki et al. 2005; McIntyre and Flecker 2006). The results show the importance of estimating turnover times and discrimination factors in the laboratory before gathering data in the field. If we assumed the commonly used discrimination factors of $1 \%$ for $\delta^{13} \mathrm{C}$ and $3.4 \%$ for $\delta^{15} \mathrm{~N}$ for muscle, we might draw very different conclusions from the field isotopic data. By using positive and negative control groups in the laboratory feeding trial we were able to show that $P$. disjunctivus consuming the artificial wood-detritus simply were not starving, but were in negative nitrogen balance. Furthermore, our results offer additional evidence that $P$. disjunctivus does not efficiently digest cellulose in their digestive tracts.

Because several species belonging to the genus Pterygoplichthys represent the dominant ichthyofauna in many novel habitats (Mendoza et al. 2007; Nico et al. 2009), it is of interest to understand the specific trophic level at which they are feeding. Our gut content analyses (German 2009b), and now stable 
isotopic data, provide ample evidence that $P$. disjunctivus is detritivorous in Florida, but is not contributing to the direct turnover of recalcitrant organic matter. This information could be valuable in making management decisions regarding habitats in which $P$. disjunctivus and/or other species in the genus Pterygoplichthys have invaded in Florida and beyond. Moreover, the turnover rates and discrimination factors gathered for $P$. disjunctivus' tissues in this study can potentially be used to better understand their diets in other Floridian habitats.

Acknowledgements The authors wish to thank David $\mathrm{H}$. Evans, Karen A. Bjorndal, Douglas J. Levey, Larry M. Page, Kim Reich, and Craig Layman for guidance and comments on an earlier form of this manuscript. Jennette Villeda, Ana Ruiz, Daniel Neuberger, Ankita Patel, Meaghan Callahan, Rosalie Bittong, Robyn Monckton, Alfred Thomson, Dieldrich Bermudez, Jada-Simone White, Samantha Hilber, and Craig Duxbury assisted with the collection, dissection, and/or processing of fishes and tissues. We are indebted to Jason Curtis of the light isotope laboratory, Department of Geology, University of Florida (UF). We thank the Barker-Emmerson family in Orlando, FL, for giving access to their land and private spring (Starbuck Spring), and Hartz-Mountain Corporation for donating $50 \mathrm{~kg}$ of Wardley ${ }^{\circledR}$ algae discs to our project. All handling of fish from capture to euthanasia was conducted under approved protocols D995 and E822 of the Institutional Animal Care and Use Committee of the University of Florida, which ensures that all research was conducted under the current laws of the United States of America. This project was funded by the UF Mentoring Opportunity Program, National Science Foundation (NSF) GK-12 Research Stipends, the Archie Carr Center for Sea Turtle Research, an American Society of Ichthyologists and Herpetologists Raney Award, and NSF grant IOB-0519579 (D.H. Evans, PI).

Open Access This article is distributed under the terms of the Creative Commons Attribution Noncommercial License which permits any noncommercial use, distribution, and reproduction in any medium, provided the original author(s) and source are credited.

\section{References}

Belk MC, Lydeard C (1994) Effect of Gambusia holbrooki on a similar-sized, syntopic poeciliid, Heterandria formosa: competitor or predator? Copeia 1994:296-302

Berg B, McClaugherty C (2008) Plant litter: decomposition, humus formation, and carbon sequesteration. SpringerVerlag, Berlin

Bowen SH, Lutz EV, Ahlgren MO (1995) Dietary protein and energy as determinants of food quality: trophic strategies compared. Ecology 76:899-907

Bowling D, Pataki D, Randerson J (2008) Carbon isotopes in terrestrial ecosystem pools and $\mathrm{CO}_{2}$ fluxes. New Phytol 178:24-40
Carleton SA, Kelly L, Anderson-Sprecher R, Martínez del Rio C (2008) Should we use one-, or multi-compartment models to describe ${ }^{13} \mathrm{C}$ incorporation into animal tissues? Rapid Commun Mass Spectrom 22:3008-3014

Caut S, Angulo E, Courchamp F (2009) Variation in discrimination factors $\left(\Delta^{15} \mathrm{~N}\right.$ and $\left.\Delta^{13} \mathrm{C}\right)$ : the effect of diet isotopic values and applications for diet reconstruction. J Appl Ecol 46:443-453

Church MR, Ebersole JL, Rensmeyer KM, Couture RB, Barrows FT, Noakes DLG (2009) Mucous: a new tissue fraction for rapid determination of fish diet switching using stable isotope analysis. Can J Fish Aquat Sci 66:1-5

da Cruz AL, Pedretti ACE, Fernandes MN (2009) Stereological estimation of the surface area and oxygen diffusing capacity of the respiratory stomach of the air-breathing armored catfish Pterygoplichthys anisitsi (Teleostei: Loricariidae). J Morphol 270:601-614

Doucett RR, Booth RK, Power G, McKinley RS (1999) Effects of the spawning migration on the nutritional status of anadromous Atlantic salmon (Salmo salar): insights from stableisotope analysis. Can J Fish Aquat Sci 56:2172-2180

Etnier D, Starnes W (1993) The fishes of Tennessee. University of Tennessee Press, Knoxville, TN

Evans-White M, Dodds WK, Gray LJ, Fritz KM (2001) A comparison of the trophic ecology of the crayfishes (Orconectes nais (Faxon) and Orconectes neglectus (Faxon)) and the central stoneroller minnow (Campostoma anomalum (Rafinesque)): omnivory in a tallgrass prarie stream. Hydrobiol 462:131-144

Focken U (2004) Feeding fish with diets of different ratios of C3-and C4-plant-derived ingredients: a laboratory analysis with implications for the back-calculation of diet from stable isotope data. Rapid Commun Mass Spectrom 18:2087-2092

Fry B (2007) Stable isotope ecology. Springer, New York

Fry B, Sherr E (1984) $\delta^{13} \mathrm{C}$ measurements as indicators of carbon flow in marine and freshwater ecosystems. Contrib Mar Sci 27:13-47

Gamboa-Delgado J, Cañavate JP, Zerolo R, Le Vay L (2008) Natural carbon stable isotope ratios as indicators of the relative contribution of live and inert diets to growth in larval Senegalese sole (Solea senegalensis). Aquacult 280:190-197

Gaudinski JB, Dawson TE, Quideau S, Schuur EAG, Roden JS, Trumbore SE, Sandquist DR, Oh SW, Wasylishen RE (2005) Comparative analysis of cellulose preparation techniques for use with ${ }^{13} \mathrm{C},{ }^{14} \mathrm{C}$, and ${ }^{18} \mathrm{O}$ isotopic measurements. Anal Chem 77:7212-7224

Gaye-Siessegger J, Focken U, Muetzel S, Abel H, Becker K (2004) Feeding level and individual metabolic rate affect $\mathrm{d} 13 \mathrm{C}$ and $\mathrm{d} 15 \mathrm{~N}$ values in carp: implications for food web studies. Oecologia 138:175-183

German DP (2009a) Do herbivorous minnows have "plug-flow reactor" guts? Evidence from digestive enzyme activities, gastrointestinal fermentation, and luminal nutrient concentrations. J Comp Physiol B 179:759-771

German DP (2009b) Inside the guts of wood-eating catfishes: can they digest wood? J Comp Physiol B 179:1011-1023

German DP, Bittong RA (2009) Digestive enzyme activities and gastrointestinal fermentation in wood-eating catfishes. J Comp Physiol B 179:1025-1042 
German DP, Neuberger DT, Callahan MN, Lizardo NR, Evans DH (2010) Feast to famine: the effects of dietary quality and quantity on the gut structure and function of a detritivorous catfish (Teleostei: Loricariidae). Comp Biochem Physiol A 155:281-293

Guelinckx J, Maes J, Van Den Driessche P, Geysen B, Dehairs F, Ollevier $\mathrm{F}$ (2007) Changes in $\delta^{13} \mathrm{C}$ and $\delta^{15} \mathrm{~N}$ in different tissues of juvenile sand goby Pomatoschistus minutus: a laboratory diet-switch experiment. Mar Ecol Prog Ser 341:205-215

Guimarães IG, Pezzato LE, Barros MM (2008) Amino acid availability and protein digestibility of several protein sources for Nile Tilapia, Oreochromis niloticus. Aquacult Nutr 14:396-404

Hanisch JR, Tonn WM, Paszkowski CA, Scrimgeour GJ (2010) $\delta^{13} \mathrm{C}$ and $\delta^{15} \mathrm{~N}$ signatures in muscle and fin tissues: nonlethal sampling methods for stable isotope analysis of Salmonids. N Am J Fish Manage 30:1-11

Hesslein R, Hallard K, Ramlal P (1993) Replacement of sulfur, carbon, and nitrogen in tissues of growing broad whitefish (Coregonus nasus) in response to a change in diet traced by d34S, d13C, d15N. Can J Fish Aquat Sci 50:2071-2076

Jardine T, MacLatchy D, Fairchild W, Cunjak R, Brown S (2004) Rapid carbon turnover during growth of Atlantic Salmon (Salmo salar) smolts in sea water, and evidence for reduced food consumption by growth-stunts. Hydrobiol 527:63-75

Karasov WH, Martínez del Rio C (2007) Physiological ecology: how animals process energy, nutrients, and toxins. Princeton University Press, Princeton

Kelly MH, Hagar WG, Jardine TD, Cunjak RA (2006) Nonlethal sampling of sunfish and slimy sculpin for stable isotope analysis: how scale and fin tissue compare with muscle tissue. N Am J Fish Manag 26:921-925

Klock JH, Wieland A, Seifert R, Michaelis W (2007) Extracellular polymeric substances (EPS) from cyanobacterial mats: characterisation and isolation method optimisation. Mar Biol 152:1077-1085

Krogdahl Å, Hemre GI, Mommsen T (2005) Carbohydrates in fish nutrition: digestion and absorption in postlarval stages. Aquacult Nutr 11:103-122

Leavitt SW, Danzer DR (1993) Method for batch processing small wood samples to holocellulose for stable-carbon isotope analysis. Anal Chem 65:87-89

Leenhouwers JI, Adjei-Boateng D, Verreth JAJ, Schrama JW (2006) Digesta viscosity, nutrient digestibility and organ weights in African catfish (Clarias gariepinus) fed diets supplemented with different levels of a soluble non-starch polysaccharide. Aquacult Nutr 12:111-116

Leppard GG (1995) The characterization of algal and microbial mucilages and their aggregates in aquatic ecosystems. Sci Total Environ 165:103-131

Lloret J, Planes S (2003) Condition, feeding, and reproductive potential of white seabream Diplodus sargus as indicators of habitat quality and the effect of reserve protection in the northwest Mediterranean. Mar Ecol Prog Ser 248:197-208

MacAvoy S, Macko S, Garman G (2001) Isotopic turnover in aquatic predators: quantifying the exploitation of migratory prey. Can J Fish Aquat Sci 58:923-932

Martínez del Rio C, Wolf BO (2005) Mass balance models for animal isotopic ecology: linking diet's stoichiometry and physiological processes with broad scale ecological patterns. In: Starck J, Wang $\mathrm{T}$ (eds) Physiological and ecological adaptations to feeding in vertebrates. Science, Berlin, pp 141-174

Martínez del Rio C, Wolf N, Carleton SA, Gannes LZ (2009) Isotopic ecology ten years after a call for more laboratory experiments. Biol Rev 84:91-111

Masagounder K, Firman JD, Hayward RS, Sun S, Brown PB (2009) Apparent digestibilities of common feedstuffs for bluegill Lepomis machrochirus and largemouth bass Micropterus salmoides using individual test ingredients. Aquacult Nutr 15:29-37

McCue MD, Pollock E (2008) Stable isotopes may provide evidence for starvation in reptiles. Rap Comm Mass Spectrom 22:2307-2314

McIntyre P, Flecker A (2006) Rapid turnover of tissue nitrogen of primary consumers in tropical freshwaters. Oecologia 148:12-21

Mendoza R, Contreras Balderas S, Ramirez C, Koleff P, Álvarez P, Aguilar V (2007) Los peces diablo: especies invasoras de alto impacto. Biodiversitas 70:2-5

Mill A, Pinnegar JK, Polunin NVC (2007) Explaining isotope trophic-step fractionation: why herbivorous fish are different. Funct Ecol 21:1137-1145

Napolitano GE, Shantha NC, HIll WR, Luttrella AE (1996) Lipid and fatty acid compositions of stream periphyton and stoneroller minnows (Campostoma anomalum): trophic and environmental implications. Arch Hydrobiol $137: 211-225$

Nichols SJ, Garling D (2000) Food-web dynamics and trophiclevel interactions in a multispecies community of freshwater unionids. Can J Zool 78:871-882

Nico L (2005) Changes in the fish fauna of the Kissimmee River basin, penninsular Florida: non-native additions. In: Rinne JN, Hughes RM, Calamusso B (eds) Historical changes in large river fish assemblages of the Americas, Symposium 45. American Fisheries Society, Bethesda, pp 523-556

Nico LG, Jelks HL, Tuten T (2009) Non-native suckermouth armored catfishes in Florida: description of nest burrows and burrow colonies with assessment of shoreline conditions. Aquat Nuis Spec Res Progr Bull 09-1:1-30

Page LM, Robbins RH (2006) Identification of sailfin catfishes (Teleostei: Loricariidae) in southeastern Asia. Raff Bull Zool 54:455-457

Perga ME, Gerdeaux D (2005) 'Are fish what they eat' all year round? Oecologia 144:598-606

Pinnegar JK, Polunin NVC (1999) Differential fractionation of $\delta^{13} \mathrm{C}$ and $\delta^{15} \mathrm{~N}$ among fish tissues: implications for the study of trophic interactions. Functional Ecology 13:225-231

Reich K, Bjorndal K, Martinez del Rio C (2008) Effects of growth and tissue type on the kinetics of ${ }^{13} \mathrm{C}$ and ${ }^{15} \mathrm{~N}$ incorporation in a rapidly growing ectotherm. Oecologia 155:651-663

Robbins CT, Felicetti LA, Sponheimer M (2005) The effect of dietary protein quality on nitrogen isotope discrimination in mammals and birds. Oecologia 144:534-540

Robbins CT, Felicetti LA, Florin ST (2010) The impact of protein quality on stable nitrogen isotope ratio discrimination and assimilated diet estimation. Oecologia 162:571-579

Sakano H, Fujiwara E, Nohara S, Ueda H (2005) Estimation of nitrogen stable isotope turnover rate of Oncorhynchus nerka. Environ Biol Fish 72:13-18 
Seminoff JA, Bjorndal KA, Bolten AB (2007) Stable carbon and nitrogen isotope discrimination and turnover in pond sliders Trachemys scripta: insights for trophic study of freshwater turtles. Copeia 2007:534-542

Suzuki KW, Kasai A, Nakayama K, Tanaka M (2005) Differential isotopic enrichment and half-life among tissues in Japanese temperate bass (Lateolabrax japonicus) juveniles: implications for analyzing migration. Can J Fish Aquat Sci 62:671-678

Taylor RC, Trexler JC, Loftus WF (2001) Separating the effects of intra- and interspecific age-structured interactions in an experimental fish assemblage. Oecologia 127:143-152

Trueman C, McGill R, Guyard P (2005) The effect of growth rate on tissue-diet isotopic spacing in rapidly growing animals. An experimental study with Atlantic salmon (Salmo salar). Rap Comm Mass Spectrom 19:3239-3247

Vollaire Y, Banas D, Thomas M, Roche H (2007) Stable isotope variability in tissues of the Eurasian perch Perca fluviatilis. Comp Biochem Physiol A 148:504-509
Weber C (1991) Nouveaux taxa dans Pterygoplichthys sensu lato (Pisces, Siluriformes, Loricariidae). Rev Suisse Zool 98:637-643

Williams AJ, Trexler JC (2006) A preliminary analysis of the correlation of food-web characteristics with hydrology and nutrient gradients in the southern Everglades. Hydrobiol 569:493-504

Wills AA, Kidd ARI, Lepilina A, Poss KD (2008) Fgfs control homeostatic regeneration in adult zebrafish fins. Development 135:3063-3070

Wotton RS (2004) The ubiquity and many roles of exopolymers (EPS) in aquatic systems. Sci Mar 68 (suppl 1):13-21

Zuanon JAS, Pezzato AC, Ducatti C, Barros MM, Pezzato LE, Passos JRS (2007) Muscle $\delta 13 \mathrm{C}$ change in Nile tilapia (Oreochromis niloticus) fingerlings fed on C3-or C4-cycle plants grain-based diets. Comp Biochem Physiol A 147:761-765 